\title{
Sexual and Asexual Reproduction of Salix sitchensis and the Influence of Beaver (Castor canadensis) Herbivory on Reproductive Success
}

\author{
Travis G. Gerwing, ${ }^{1,2}$ Alyssa M. Allen Gerwing, ${ }^{1}$ \\ Eric Rapaport, ${ }^{3,4}$ and Cecilia Alström-Rapaport ${ }^{1,4}$ \\ ${ }^{1}$ Ecosystem Science and Management Program, University of Northern British Columbia, 3333 University Way, Prince George, \\ BC, Canada V2N $4 Z 9$ \\ ${ }^{2}$ Biology Department, University of New Brunswick, P.O. Box 4400, Fredericton, NB, Canada E3B 5A3 \\ ${ }^{3}$ School of Environmental Planning, University of Northern British Columbia, 3333 University Way, Prince George, \\ BC, Canada V2N $4 Z 9$ \\ ${ }^{4}$ School of Planning, Faculty of Architecture and Planning, Dalhousie University, P.O. Box 1000, Halifax, NS, Canada B3J 2X4
}

Correspondence should be addressed to Travis G. Gerwing, gerwing@unbc.ca

Received 12 September 2012; Accepted 8 October 2012

Academic Editors: J. E. Colman, M. A. Molina-Montenegro, J.-P. Rossi, and J. G. Zaller

Copyright ( $) 2012$ Travis G. Gerwing et al. This is an open access article distributed under the Creative Commons Attribution License, which permits unrestricted use, distribution, and reproduction in any medium, provided the original work is properly cited.

\begin{abstract}
The influence of beaver (Castor canadensis Kuhl) herbivory on Salix reproduction, specifically the stimulation of asexual reproduction via browsed stem fragments, is relatively unknown. This study aimed to determine if beaver herbivory stimulates asexual reproduction of riparian willows and results in mature populations dominated by clones. The survival of seedlings and asexual propagules produced by beaver browse in populations of the riparian willow Salix sitchensis (Sanson in Bongard) were quantified to determine overwinter survival at 6 experimental sites. Salix sitchensis clonal diversity, using five microsatellite markers and the polymerase chain reaction, was calculated to detect if asexual reproduction had been stimulated by beaver herbivory. No sexual propagules survived overwinter in any of our study sites. Numerous asexual propagules were observed and $0-41 \%$ survived overwinter. Each sampled individual possessed a unique multilocus genotype, and clonal diversity was 1.0. Beaver herbivory did not create current willow populations dominated by clones. Beaver herbivory and asexual reproduction appeared to have played a minor role in the reproductive strategies of $S$. sitchensis at our sites in central British Columbia, Canada.
\end{abstract}

\section{Introduction}

Whether herbivory positively or negatively influences plant reproduction is a debated topic. Depending on the species, response variable, and the seasonal pattern of the foraging, herbivory can have a negative, $[1-7]$, positive $[1,5,8]$, or neutral $[1,4,5]$ influence on plant reproduction. A relatively unexplored aspect of this interaction is the stimulation of asexual reproduction by the production and relocation of vegetative propagules via animal browsing. While some studies have reported the incidence or survival of such translocated propagules [9-15], it is still unclear if they significantly contribute to plant reproductive strategies.
Riparian habitat in central British Columbia, Canada, presents an ideal system to investigate this relationship. The dominant members of the riparian vegetative community are species of the genus Salix. Willows (Salix spp.) reproduce either sexually through wind dispersed seeds, or asexually through underground runners and severed branches or stems [10-12, 15-18]. Severed branches may play an important role in Salix colonization [19-23], once colonization has occurred, these areas of patchy vegetation can shelter sexual propagules, as well as stabilize and retain sediment. This ecosystem modification creates more habitat conducive to sexual propagule survival [19-23]. The opposite sequence of events has been observed for other populations of 
riparian vegetation. In populations of Populus nigra Linnaeus (Populus is a closely related genus to Salix within the family Salicaceae), vegetative reproduction dominated within sites and sexual reproduction initiated colonization [24]. Other species have shown a mixed reproductive strategy within a site, while sexual reproduction was responsible for colonization [25]. High genetic diversity observed in most species of riparian willows $[10,15,26-29]$, as well as the abundance of sexual propagules produced by riparian willows $[11,13,14]$ suggests that sexual reproduction may play an important role in willow reproduction.

In the riparian habitats of central British Columbia Canada, beavers (Castor canadensis Kuhl) leave evidence of their presence in the form of lodges, dams, ponds, and felled trees. Through selective foraging and the creation of dams, beavers alter forest composition and age, as well as the hydrology, temperature, and chemical properties of water ways $[30,31]$. Herbivory by beavers may alter the nutrient and secondary compound concentrations of willows [32], as well as increase basal area, diameter, abundance, and sapling recruitment $[33,34]$. Beavers may also influence the reproductive strategies of willows by removing and relocating stems during foraging, creating potential asexual propagules. This mechanism has been hypothesized to contribute to Salix planifolia's (Pursh) domination of mire habitat [9]. Conversely, other studies have suggested that beaver foraging has limited impact on willow reproduction [11-14].

Numerous potential asexual propagules, in the form of branches severed by beavers, are found in the riparian habitats of central British Columbia. It is possible that beaver herbivory may induce willow asexual reproduction and play an important role in willow reproductive strategies. The aim of this study was to examine the impact of beaver browse on willow reproduction with a particular focus on Salix sitchensis (Sanson in Bongard), one of the predominant and most heavily browsed species in riparian habitats in central British Columbia $[35,36]$. Specifically, we tested the prediction that the large numbers of potential asexual propagules produced by beaver foraging would lead to mature stands of willows dominated by clonally derived individuals. To do this, we used both field and laboratory analyses to investigate the recent and long-term reproductive history of the site, respectively. In the field we examined the establishment of seedlings and vegetative fragments of $S$. sitchensis at six riparian sites with beavers present. The pattern of sexual and asexual establishment in the field is a product of the site's recent reproductive history. Molecular genetics can be used to determine how a population has been reproducing on a longer time scale. Asexual reproduction should lead to a high predominance of clonally derived genotypes (see [15] for an example). We therefore examined clonal diversity using five microsatellite markers in populations of $S$. sitchensis at six riparian sites.

\section{Methods}

2.1. Study Sites. Six riparian sites, spread over $8000 \mathrm{~km}^{2}$ of central British Columbia Canada, were chosen for this study
(Figure 1; Table 1). No effort was made to discriminate sites based upon beaver abundance. Three of the six sites were established on large rivers: Bowron River and Bowron Bridge on the Bowron River, as well as Penny by the Fraser on the Fraser River. These sites were dominated by sandy and rocky beaches extending $25-50 \mathrm{~m}$ from the water to a dense forest composed of Salix, Alnus, Populus, Betula, Pinus, Picea, and Abies species. Present sporadically along the beach were small Salix, Alnus, and Populus individuals. Beavers at these sites did not build dams, but did construct lodges and food caches. Island Park, a floodplain island in the Nechako River, was dominated by a dense grove of tall Salix. Areas not dominated by willows were often covered with grasses and sedges, although substantial expanses of exposed sediment were also observed. Beavers at this site built lodges, several dams along an oxbow, and numerous food caches. Despite the presence of small beaver dams, no substantial beaver pond or beaver-induced flooding was observed at this site. Two sites, Camp Creek and Penny, were located on smaller creeks frequently dammed by beavers. Sporadic clumps of Salix and Alnus were found near the water while a dense mixed forest dominated $50-75 \mathrm{~m}$ from the water. The majority of these sites were dominated by shrubs, sedges and grasses, however, small sections of exposed sediment near the creeks were also present. Camp Creek and Penny possessed beaver lodges, dams, food caches, and sizeable beaver ponds. More detailed descriptions of all sites can be found in Gerwing $[35,36]$.

\subsection{Field Survey of the Short-Term Reproductive History.} During August 2007 and April-August in 2008, S. sitchensis seedlings were quantified on the portion of the study sites classified as potential germination substrate. Potential substrate was defined as at least partly exposed soil anywhere in the site, not completely covered by grass, sedges, shrubs, or water. The dimensions of this habitat were measured in situ for area calculations. Covered habitats were avoided as Cottrell [9] found no willow reproduction under sedge cover, and Barsoum [11] found the majority of seedlings on fine exposed sediments. The majority of the potential germination substrate was found near the water's edge.

Beaver-browsed stem fragments were identified by the characteristic diagonal browse pattern left on vegetative propagules. Beaver browse was counted only on potential germination substrate. In the falls of 2007 and 2008, stems browsed and abandoned by beavers, but possessing adventitious roots were denoted as rooted propagules. Those without roots were defined as unrooted propagules. To establish the overwinter survival of beaver-produced asexual propagules within the sites Camp Creek, Bowron Bridge, and Island Park, each category was marked with a characteristic colour of flagging tape in 2007 and located again the following spring. Only S. sitchensis stems were marked and identification was made possible by $S$. sitchensis' characteristic leaf and bark morphology [37].

2.3. Laboratory Analysis of Longer Term Reproductive History. Leaf samples for genetic analysis were collected from mature S. sitchensis at all sites except Penny by the Fraser (Table 1). 
TABLE 1: Characteristics of riparian study sites in central British Columbia, Canada. The size of study sites was measured at the lowest point of the yearly fluctuating water levels. $N$ represents the number of individuals sampled for the genetic analysis, and the percentage of the total population sampled is given in parentheses.

\begin{tabular}{|c|c|c|c|c|}
\hline Site & GPS coordinates & Predominant soil type & Size $\left(\mathrm{m}^{2}\right)$ & $N(\%)$ \\
\hline Camp Creek & $\begin{array}{c}54^{\circ} 3^{\prime} 23.70^{\prime \prime} \mathrm{N} 122^{\circ} \\
3^{\prime} 37.86^{\prime \prime} \mathrm{W}\end{array}$ & Sandy loam & 6400 & $95(50)$ \\
\hline Penny & $\begin{array}{c}53^{\circ} 50^{\prime} 0.15^{\prime \prime} \mathrm{N} \\
121^{\circ} 20^{\prime} 27.43^{\prime \prime} \mathrm{W}\end{array}$ & Clay loam & 5600 & $49(25)$ \\
\hline Bowron Bridge & $\begin{array}{c}54^{\circ} 3^{\prime} 1.59^{\prime \prime} \mathrm{N} \\
121^{\circ} 50^{\prime} 13.97^{\prime \prime} \mathrm{W}\end{array}$ & Sandy soil & 6000 & $20(75)$ \\
\hline Bowron River & $\begin{array}{c}54^{\circ} 2^{\prime} 41.31^{\prime \prime} \mathrm{N} 122^{\circ} \\
1^{\prime} 42.49^{\prime \prime} \mathrm{W}\end{array}$ & Gravel and detritus & 4500 & $16(60)$ \\
\hline Penny by the Fraser & $\begin{array}{c}53^{\circ} 50^{\prime} 22.61^{\prime \prime} \mathrm{N} \\
121^{\circ} 19^{\prime} 14.33^{\prime \prime} \mathrm{W}\end{array}$ & Sandy soil & 8800 & - \\
\hline Island Park & $\begin{array}{c}53^{\circ} 57^{\prime} 54.60^{\prime \prime} \mathrm{N} \\
122^{\circ} 55^{\prime} 51.40^{\prime \prime} \mathrm{W}\end{array}$ & Sandy soil and clay loam & 6000 & $105(5)$ \\
\hline
\end{tabular}

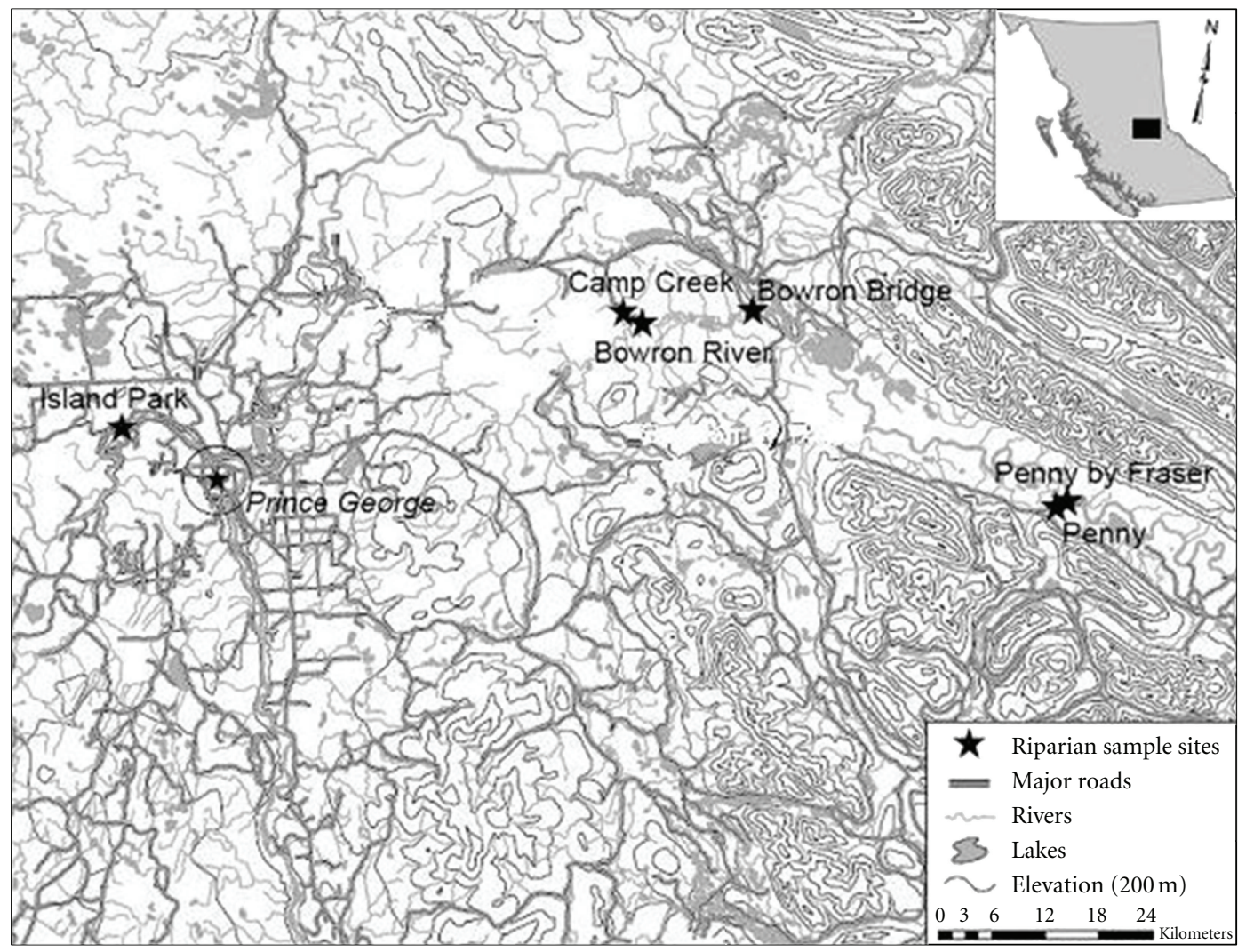

FIgURE 1: Location of riparian study sites in central British Columbia, Canada.

At Camp Creek and Penny, all individuals were sampled and a random subset was selected for analysis. At Bowron River and Bowron Bridge, where the mature populations formed narrow bands of individuals along the rivers, one individual was sampled every $10 \mathrm{~m}$ for $160 \mathrm{~m}$ and $200 \mathrm{~m}$, respectively. At Island Park ten, $5 \mathrm{~m} \times 5 \mathrm{~m}$, plots separated by $25 \mathrm{~m}$, were established along the center of the island. Along the south side of the island a $200 \mathrm{~m}$ transect was also established. All S. sitchensis were sampled within these plots and a random subset of these individuals was analyzed. Samples were collected randomly as our goal was to determine if populations were dominated by clones not to examine fine scale clonal structure.

Leaf tissue was collected and stored at $-80^{\circ} \mathrm{C}$. Genomic DNA was isolated using QIAGEN DNeasy Plant Mini Kit. Extraction protocol was the unmodified kit instructions. Five microsatellite primers (Karp_SB24, Karp_SB80, Karp_SB85, Karp_SB199, and Karp_SB201) derived for Salix burjatica 
Nasarow (Barker et al., 2003 [38]), that had previously shown polymorphism in $S$. sitchensis were used for screening samples in our collection. The polymerase chain reaction (PCR) procedure was $5 \mathrm{ng}$ DNA, $25 \mathrm{ng}$ forward primer, $25 \mathrm{ng}$ reverse primer, $200 \mu \mathrm{m}$ of each dNTP, 0.5 units of Taq DNA polymerase, $20 \mu \mathrm{m} 10 \mathrm{X}$ buffer, and $1.5 \mathrm{mM}$ $\mathrm{MgCl}_{2}$ (reagents from QIAGEN). Total reaction volume was $12.5 \mu \mathrm{L}$. Thermocycler conditions were $94^{\circ} \mathrm{C} / 2 \mathrm{~min} ; 35$ cycles of: $94^{\circ} \mathrm{C} / 40 \mathrm{~s}, 54^{\circ} \mathrm{C} / 1 \mathrm{~min}$, and $72^{\circ} \mathrm{C} / 2 \mathrm{~min}$, followed by $72^{\circ} \mathrm{C} / 20$ min [38]. Samples were run on a Beckman-Coulter CEQ800 to determine fragment/allele size. GeneCLONE 2.0 [39] was used to determine the number of ramets with identical multilocus genotypes at five microsatellite loci. Clonal diversity was calculated according to Dorken and Eckert as follows [40]:

$$
R=\frac{G-1}{N-1},
$$

where $N$ is the sample size and $G$ is the number of distinct genotypes (see also [39]).

\section{Results}

3.1. Field Survey of the Short-Term Reproductive History. During our study period, populations of S. sitchensis were comprised entirely of established mature individuals. Due to extensive flooding in 2006, 2007, and 2008, no seedlings, of any age, survived over winter in our study sites. Flooding covered all portions of our study sites for several weeks during seed release of $S$. sitchensis, resulting in no refugia for seedlings or seeds.

Five alive willow translocated stem fragments found at Island Park were not the result of beaver browse. At the remaining sites, $\sim 10$ observed fragments were not the result of beaver browse and none of these fragments was alive. Beaver herbivory was the predominant source of severed willow fragments in this study area during this time. Beaver cut willow fragments, both with adventitious roots and without, were observed at all sites and years except at Penny by the Fraser in 2007, and at Bowron River in 2008 (Table 2). In total, $42 \%$ of the cut stems produced adventitious roots the same year. Among the stems with roots marked in 2007, $20 \%, 0 \%$, and $41 \%$ of the fragments recovered in 2008 were still displaying roots at Camp Creek, Bowron River, and Island Park, respectively (Table 2). Stems marked in 2007 and relocated in 2008 that were without roots had all died over winter. Marked stems not relocated were assumed to have been washed downstream.

3.2. Laboratory Analysis of Longer Reproductive History. We found 103 alleles for five microsatellite loci among all individuals sampled. All 286 sampled S. sitchensis individuals possessed a unique multilocus genotype and clonal diversity was therefore 1.0. More detailed information on the genetic structure of these populations can be found in Gerwing [35].

\section{Discussion}

As in our study, low survival of Salicaceae sexual propagules has been documented before $[9,11,13,22]$. Abundant but variable levels of asexual propagules have also been observed before $[11,12,14]$. On the Drome River in France, 0.056 vegetative propagules per $\mathrm{m}^{2}$ were observed by Barsoum [11], which was within the range of values observed in central British Columbia. Higher survival rates of asexual propagules when compared to sexual propagules have been observed by Cottrell [9], Barsoum [11], and Moggridge and Gurnell [22]. The higher survival of asexual propagules may be due to carbohydrate reserves, preformed root, and shoot primordial [41], or the more resilient nature of branches versus seedlings. Survival of asexual propagules varied from $0-41 \%$ and this is most likely a result of variation in topography and the vertical structure of a site. None of the marked asexual propagules survived at Bowron River, which was a bare stretch of beach with few trees, stumps, bends, or other features to retain asexual propagules. It is likely that all of our propagules were washed downstream. Conversely, Island Park had the highest survival rate, and possessed the greatest physical heterogeneity. Island Park contained dense thickets of $S$. sitchensis, numerous piles of dead trees of various sizes, and abundant topographic variation. The abundance of features able to prevent asexual propagules from being washed downstream is most likely responsible for the higher survival rate of asexual propagules. Twenty percent of the asexual propagules survived at Camp Creek. Camp Creek had ample vertical structure in the form of dense thickets of grasses and sedges, dead trees, as well as numerous bends and elevation changes. While Camp Creek had more features able to retain asexual propagules than Bowron River, it possessed fewer features than Island Park. This is most likely the cause of Camp Creek's asexual propagule survival being between that of Island Park and Bowron River. While features that are able to retain asexual propagules are most likely responsible for the observed variation in survival, factors such as soil type may also have played an important role. Future studies need to investigate the influence of other factors on the trends observed here.

The findings of the field and genetic analyses are, at first glance, contradictory. The field analysis suggested that the recent reproductive history of these populations was dominated by asexual reproduction, as only asexual propagules survived over winter. However, we did not find any mature individuals with shared genotypes. A large proportion of each population was genotyped, and the absence of shared genotypes suggests that asexual reproduction played a minor role in our populations. Stamati et al. [42] also found that field studies suggested the dominance of asexual reproduction; however, genetic analysis revealed that sexual reproduction dominated in populations of subarctic willows. Stamati et al. [42] postulated this may be due to continuous low levels of unobserved sexual reproduction, or sporadic bursts of sexual reproduction coinciding with optimal conditions for survival. Another possible explanation is that asexual propagules are important in colonization, while sexual propagules are responsible for population growth [19-23]. If 
TABLE 2: Number of beaver cut willow stems at six riparian sites in central British Columbia. In parentheses are the numbers of fragments that were displaying roots when recaptured the following spring.

\begin{tabular}{lcccc}
\hline Year & Site & $\begin{array}{c}\text { No. rooted vegetative } \\
\text { fragments }\end{array}$ & $\begin{array}{c}\text { No. vegetative fragments } \\
\text { without roots }\end{array}$ & $\begin{array}{c}\text { No. rooted vegetative } \\
\text { fragments per } \mathrm{m}^{2}\end{array}$ \\
\hline 2007 & Bowron Bridge & $15(0)$ & 48 & 0.0025 \\
2008 & Bowron Bridge & 46 & 64 & 0.0077 \\
2007 & Bowron River & 1 & 23 & 0.0004 \\
2008 & Bowron River & 0 & 0 & 0.0000 \\
2007 & Camp Creek & $5(1)$ & 261 & 0.0008 \\
2008 & Camp Creek & 264 & 143 & 0.0415 \\
2007 & Island Park & $136(56)$ & 271 & 0.0227 \\
2008 & Island Park & 94 & 90 & 0.0157 \\
2007 & Penny & 10 & 48 & 0.0018 \\
2008 & Penny & 91 & 0 & 0.0161 \\
2007 & Penny by the Fraser & 0 & 22 & 0.0000 \\
2008 & Penny by the Fraser & 37 & 22 & 0.0042 \\
\hline
\end{tabular}

this was occurring, beavers would be crucial to this process, as nearly $100 \%$ of the asexual propagules in our study area were produced by beaver browse. Our study was not designed to differentiate between these hypotheses; however, all are possible and are not necessarily mutually exclusive. Further investigation into these processes is a crucial next step in this system.

Studies examining the influence of beaver browse on riparian plant reproduction have reported a variety of findings. Lin et al. [15] found numerous clonal genotypes in populations of Salix purpurea (Linnaeus). They attributed these clonal genotypes to vegetative reproduction, however, they were unable to differentiate between beaver-produced propagules, mechanically produced propagules, or anthropogenic propagules. Barsoum [11] found that $12 \%$ of all asexual propagules and $50 \%$ of coppice regrowth in Salix alba (Linnaeus) was due to beaver browse. The $12 \%$ of asexual propagules created by beaver foraging observed by Barsoum [11] is contrasted by the nearly $100 \%$ of vegetative propagules resulting from beaver foraging in our study. Barsoum [11] also stated that a large proportion of the vegetative propagules of Populus nigra observed on sandbars were a result of beaver placement. Jones et al. [43] observed that $35-40 \%$ of beaver-felled willows in Scotland showed regrowth. On the other hand, Rood et al. [12] excavated Populus saplings along the Elk River in British Columbia and found that only $7 \%$ of examined saplings grew from beaver browsed asexual propagules. Cooper et al. [14] also examined established vegetative propagules and concluded that beaver browse played no role in willow reproduction. The results of our study are in agreement with the findings of Rood et al. [12] and Cooper et al. [14]. While asexual propagules were abundant and no sexual propagules survived over winter, none of the mature trees sampled for the genetic analysis shared a genotype. The apparent dominance of sexual propagules, despite their poor survival over winter, is likely a result of sporadic peaks of sexual reproduction coinciding with optimal conditions for survival. Regardless, sexual reproduction appeared to dominate in the mature willow stands in this region, and beaver herbivory did not result in stands dominated by clones.

The inter-study disparity over the potential impacts of beaver herbivory on the reproduction of riparian vegetation may be based upon site variability. Differing levels of beaver activity, site topography, weather, and hydrological as well as historic events may have contributed to the observed variation. Different climatic conditions may greatly influence not only propagule survival, but beaver activity as well. Barsoum [11] also investigated a different species of beaver, the European beaver (Castor fiber Linnaeus), while our study looked at $C$. canadensis. The two species show differences in reproductive rates and dam construction $[44,45]$, potentially influencing beaver impacts on riparian populations. The finding of Cooper et al. [14], that beaver forage had no impact on willow reproduction, may be due to low levels of beaver activity. Cooper et al. [14] reported that few beaver dams were currently being built in their study area as the population had declined substantial over the past 60 years. The impact of beaver foraging on willow reproduction may have been minimal, as foraging activity would be slight or nonexistent. Differences in soil types may also influence the success of sexual and asexual propagules. Determining the influence of soil type on the trends observed in this study is a crucial next step for this system. Despite the variation within and between studies, beaver herbivory did not result in populations dominated by asexual propagules in our region. Beaver herbivory, in the form of willow asexual propagules, appeared to have minimal influence on the reproduction of S. sitchensis. Understanding the role beaver-produced asexual propagules may play in colonization and site modification is a crucial next step in understanding the influence of beaver herbivory on riparian plants.

More generally, this study adds to the body of literature on plant-herbivore interactions. Our results suggest that beavers played a minor role in willow reproduction in our study sites. However, other studies have postulated that beavers may play a significant role in riparian plant reproduction $[9,11]$. This contradiction, combined with 
the potential role beaver-induced asexual propagules may play in site colonization and modification [19-23], further complicates plant-herbivore interactions. As mentioned above, the nature of the plant-herbivore interaction depends on the species studied, the response variables examined, and the seasonal pattern of the foraging [1-8]. The results of our study, when compared with the literature, add to this list of variables by suggesting that plant-herbivore interactions may vary with species, habitat, successional stage, and method of reproduction. Care must be taken when extrapolating the findings of plant-herbivore interactions as substantial spatial and temporal variations exist within and between systems.

\section{Acknowledgments}

The authors thank Annika Klopp, Kathryn Berry, Brock Harpur, Ryan Thorgeirson, and Aydin Maxfield for their help with field work. This study was supported by the Natural Sciences and Engineering Research Council of Canada (NSERC) and Aleza Lake Research Forest (ALRF). They appreciate the helpful and insightful comments on an early draft of this paper by Dr. David Drolet and Dr. Jason Addison.

\section{References}

[1] A. J. Belsky, "Does herbivory benefit plants? a review of the evidence," American Naturalist, vol. 127, no. 6, pp. 870-892, 1986.

[2] V. K. Brown, A. C. Gange, I. M. Evans, and A. L. Storr, "The effect of insect herbivory on the growth and reproduction of two annual Vicia species at different stages in plant succession," The Journal of Ecology, vol. 75, no. 4, pp. 11731189, 1987.

[3] C. S. Wisdom, C. S. Crawford, and E. F. Aldon, "Influence of insect herbivory on photosynthetic area and reproduction in Gutierrezia species," The Journal of Ecology, vol. 77, no. 3, pp. 685-692, 1989.

[4] G. E. Gedge and M. A. Maun, "Effects of simulated herbivory on growth and reproduction of two beach annuals, Cakile edentula and Corispermum hyssopifolium," Canadian Journal of Botany, vol. 70, no. 12, pp. 2467-2475, 1992.

[5] G. J. Lowenberg, "Effects of floral herbivory on maternal reproduction in Sanicula arctopoides (Apiaceae)," Ecology, vol. 75, no. 2, pp. 359-369, 1994.

[6] S. Ruhren and S. N. Handel, "Herbivory constrains survival, reproduction and mutualisms when restoring nine temperate forest herbs," Journal of the Torrey Botanical Society, vol. 130, no. 1, pp. 34-42, 2003.

[7] J. J. Sullivan, "Density-dependent shoot-borer herbivory increases the age of first reproduction and mortality of neotropical tree saplings," Oecologia, vol. 136, no. 1, pp. 96106, 2003.

[8] K. N. Paige and T. G. Whitham, "Overcompensation in response to mammalian herbivory: the advantage of being eaten," American Naturalist, vol. 129, no. 3, pp. 407-416, 1987.

[9] T. Cottrell, "Willow colonization of Rocky Mountain mires," Canadian Journal of Forest Research, vol. 25, no. 2, pp. 215222, 1995.

[10] M. Lascoux, J. Thorsén, and U. Gullberg, "Population structure of a riparian willow species, Salix viminalis L," Genetical Research, vol. 68, no. 1, pp. 45-54, 1996.
[11] N. Barsoum, "Relative contributions of sexual and asexual regeneration strategies in Populus nigra and Salix alba during the first years of establishment on a braided gravel bed river," Evolutionary Ecology, vol. 15, no. 4-6, pp. 255-279, 2001.

[12] S. B. Rood, A. R. Kalischuk, M. L. Polzin, and J. H. Braatne, "Branch propagation, not cladoptosis, permits dispersive, clonal reproduction of riparian cottonwoods," Forest Ecology and Management, vol. 186, no. 1-3, pp. 227-242, 2003.

[13] V. Douhovnikoff, J. R. McBride, and R. S. Dodd, "Salix exigua clonal growth and population dynamics in relation to disturbance regime variation," Ecology, vol. 86, no. 2, pp. 446452, 2005.

[14] D. J. Cooper, J. Dickens, N. T. Hobbs, L. Christensen, and L. Landrum, "Hydrologic, geomorphic and climatic processes controlling willow establishment in a montane ecosystem," Hydrological Processes, vol. 20, no. 8, pp. 1845-1864, 2006.

[15] J. Lin, J. P. Gibbs, and L. B. Smart, "Population genetic structure of native versus naturalized sympatric shrub willows (Salix; Salicaceae)," American Journal of Botany, vol. 96, no. 4, pp. 771-785, 2009.

[16] C. Sacchi and P. Price, "Pollination of the arroyo willow, Salix lasiolepis: role of insects and wind," American Journal of Botany, vol. 75, no. 9, pp. 1387-1393, 1988.

[17] C. F. Sacchi, P. W. Price, T. P. Craig, and J. K. Itami, "Impact of shoot galler attack on sexual reproduction in the arroyo willow," Ecology, vol. 69, no. 6, pp. 2021-2030, 1988.

[18] S. Tamura and G. Kudo, "Wind pollination and insect pollination of two temperate willow species, Salix miyabeana and Salix sachalinensis," Plant Ecology, vol. 147, no. 2, pp. 185192, 2000.

[19] P. J. Edwards, J. Kollmann, A. M. Gurnell, G. E. Petts, K. Tockner, and J. V. Ward, "A conceptual model of vegetation dynamics of gravel bars of a large Alpine river," Wetlands Ecology and Management, vol. 7, no. 3, pp. 141-153, 1999.

[20] J. Nachtergaele, J. Poesen, L. Vandekerckhove, D. Oostwoud Wijdenes, and M. Roxo, "Riparian vegetation and island formation along the gravel-bed Fiume Tagliamento, Italy," Earth Surface Processes and Landforms, vol. 26, no. 1, pp. 3162, 2001.

[21] A. M. Gurnell and G. E. Petts, "Island-dominated landscapes of large floodplain rivers, a European perspective," Freshwater Biology, vol. 47, no. 4, pp. 581-600, 2002.

[22] H. L. Moggridge and A. M. Gurnell, "Controls on the sexual and asexual regeneration of Salicaceae along a highly dynamic, braided river system," Aquatic Sciences, vol. 71, no. 3, pp. 305317, 2009.

[23] I. Schnauder and H. L. Moggridge, "Vegetation and hydraulicmorphological interactions at the individual plant, patch and channel scale," Aquatic Sciences, vol. 71, no. 3, pp. 318-330, 2009.

[24] P. Arens, H. Coops, J. Jansen, and B. Vosman, "Molecular genetic analysis of black poplar (Populus nigra L.) along Dutch rivers," Molecular Ecology, vol. 7, no. 1, pp. 11-18, 1998.

[25] C. Lian, R. Oishi, N. Miyashita et al., "Genetic structure and reproduction dynamics of Salix reinii during primary succession on Mount Fuji, as revealed by nuclear and chloroplast microsatellite analysis," Molecular Ecology, vol. 12, no. 3, pp. 609-618, 2003.

[26] S. Brunsfeld, D. Soltis, and P. Soltis, "Patterns of genetic variation in Salix section Longifoliae (Salicaceae)," American Journal of Botany, vol. 78, no. 6, pp. 855-869, 1991.

[27] B. G. Purdy and R. J. Bayer, "Allozyme variation in the Athabasca sand dune endemic, Salix silicicola, and the closely 
related widespread species, S. alaxensis," Systematic Botany, vol. 20, no. 2, pp. 179-190, 1995.

[28] A. Rottenberg, E. Nevo, and D. Zohary, "Genetic variability in sexually dimorphic and monomorphic populations of Populus euphratica (Salicaceae)," Canadian Journal of Forest Research, vol. 30, no. 3, pp. 482-486, 2000.

[29] S. Kikuchi, W. Suzuki, and N. Sashimura, "Gene flow in an endangered willow Salix hukaoana (Salicaceae) in natural and fragmented riparian landscapes," Conservation Genetics, vol. 12, no. 1, pp. 79-89, 2011.

[30] R. Naiman, C. Johnston, and J. Kelley, "Alteration of North American streams by beaver," BioScience, vol. 38, no. 11, pp. 753-762, 1988.

[31] R. J. Naiman, J. M. Melillo, and J. E. Hobbie, "Ecosystem alteration of boreal forest streams by beaver ( Castor canadensis)," Ecology, vol. 67, no. 5, pp. 1254-1269, 1986.

[32] A. J. Veraart, B. A. Nolet, F. Rosell, and P. P. de Vries, "Simulated winter browsing may lead to induced susceptibility of willows to beavers in spring," Canadian Journal of Zoology, vol. 84, no. 12, pp. 1733-1742, 2006.

[33] R. R. Kindschy, "Response of red willow to beaver use in southeastern Oregon," Journal of Wildlife Management, vol. 49, no. 1, pp. 26-28, 1985.

[34] N. T. Donkor and J. M. Fryxell, "Impact of beaver foraging on structure of lowland boreal forests of Algonquin Provincial Park, Ontario," Forest Ecology and Management, vol. 118, no. 1-3, pp. 83-92, 1999.

[35] T. G. Gerwing, "Reproductive ecology of the sitka willow (Salix sitchensis)," in Biology, p. 83, University of Northern British Columbia, British Columbia, Canada, 2009.

[36] T. G. Gerwing, C. J. Johnson, and C. Alström-Rapaport, "Factors influencing forage selection by the North American beaver (Castor canadensis)," Mammalian Biology. In press.

[37] T. C. Brayshaw, Catkin-Bearing Plants of British Columbia, Royal British Columbia Museum, British Columbia, Canada, 1996.

[38] J. H. A. Barker, A. Pahlich, S. Trybush, K. J. Edwards, and A. Karp, "Microsatellite markers for diverse Salix species," Molecular Ecology Notes, vol. 3, no. 1, pp. 4-6, 2003.

[39] S. Arnaud-Haond, C. M. Duarte, F. Alberto, and E. A. Serrão, "Standardizing methods to address clonality in population studies," Molecular Ecology, vol. 16, no. 24, pp. 5115-5139, 2007.

[40] M. E. Dorken and C. G. Eckert, "Severely reduced sexual reproduction in northern populations of a clonal plant, Decodonverticillatus (Lythraceae)," The Journal of Ecology, vol. 89, no. 3, pp. 339-350, 2001.

[41] G. Schier and R. Campbell, "Differences among Populas species in ability to form adventitious shoots and roots," Canadian Journal of Forest Research, vol. 6, no. 3, pp. 253-261, 1976.

[42] K. Stamati, P. M. Hollingsworth, and J. Russell, "Patterns of clonal diversity in three species of sub-arctic willow (Salix lanata, Salix lapponum and Salix herbacea)," Plant Systematics and Evolution, vol. 269, no. 1-2, pp. 75-88, 2007.

[43] K. Jones, D. Gilvear, N. Willby, and M. Gaywood, "Willow (Salix spp.) and aspen (Populus tremula) regrowth after felling by the Eurasian beaver (Castor fiber): implications for riparian woodland conservation in Scotland," Aquatic Conservation, vol. 19, no. 1, pp. 75-87, 2009.

[44] B. A. Nolet and F. Rosell, "Comeback of the beaver Castor fiber: an overview of old and new conservation problems," Biological Conservation, vol. 83, no. 2, pp. 165-173, 1998.
[45] P. Collen and R. J. Gibson, "The general ecology of beavers (Castor spp.), as related to their influence on stream ecosystems and riparian habitats, and the subsequent effects on fish-a review," Reviews in Fish Biology and Fisheries, vol. 10, no. 4, pp. 439-461, 2000. 

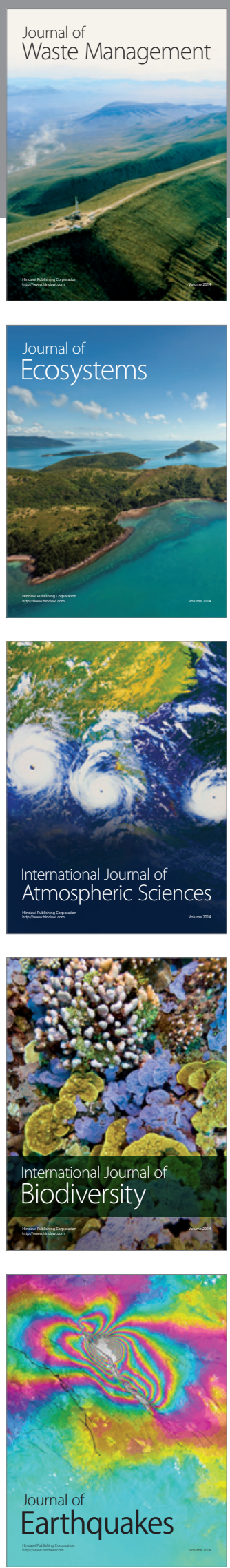
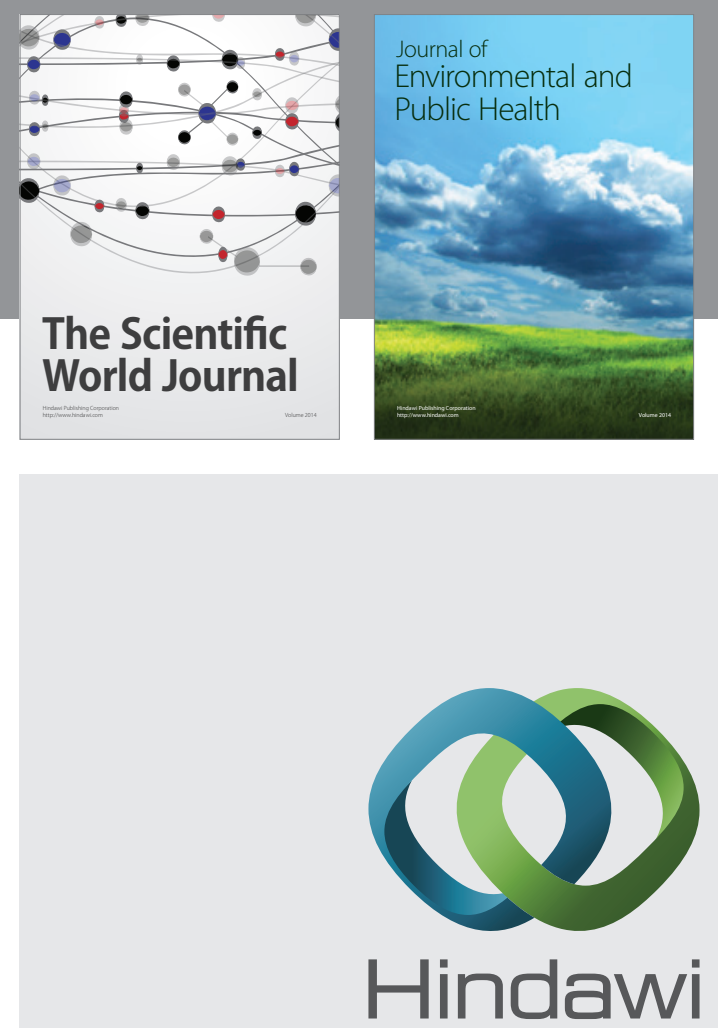

Submit your manuscripts at

http://www.hindawi.com
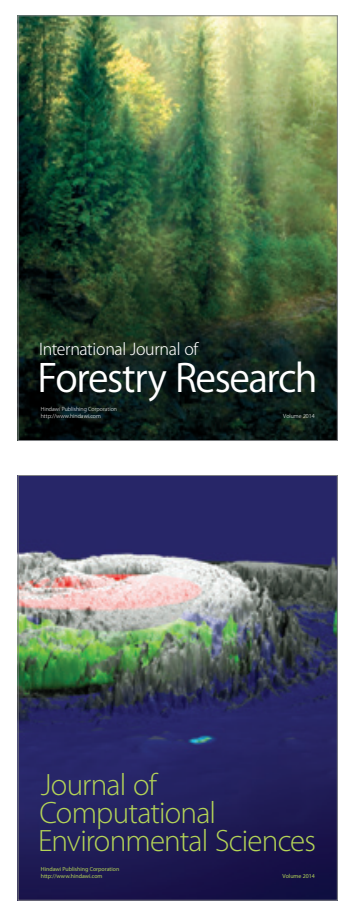
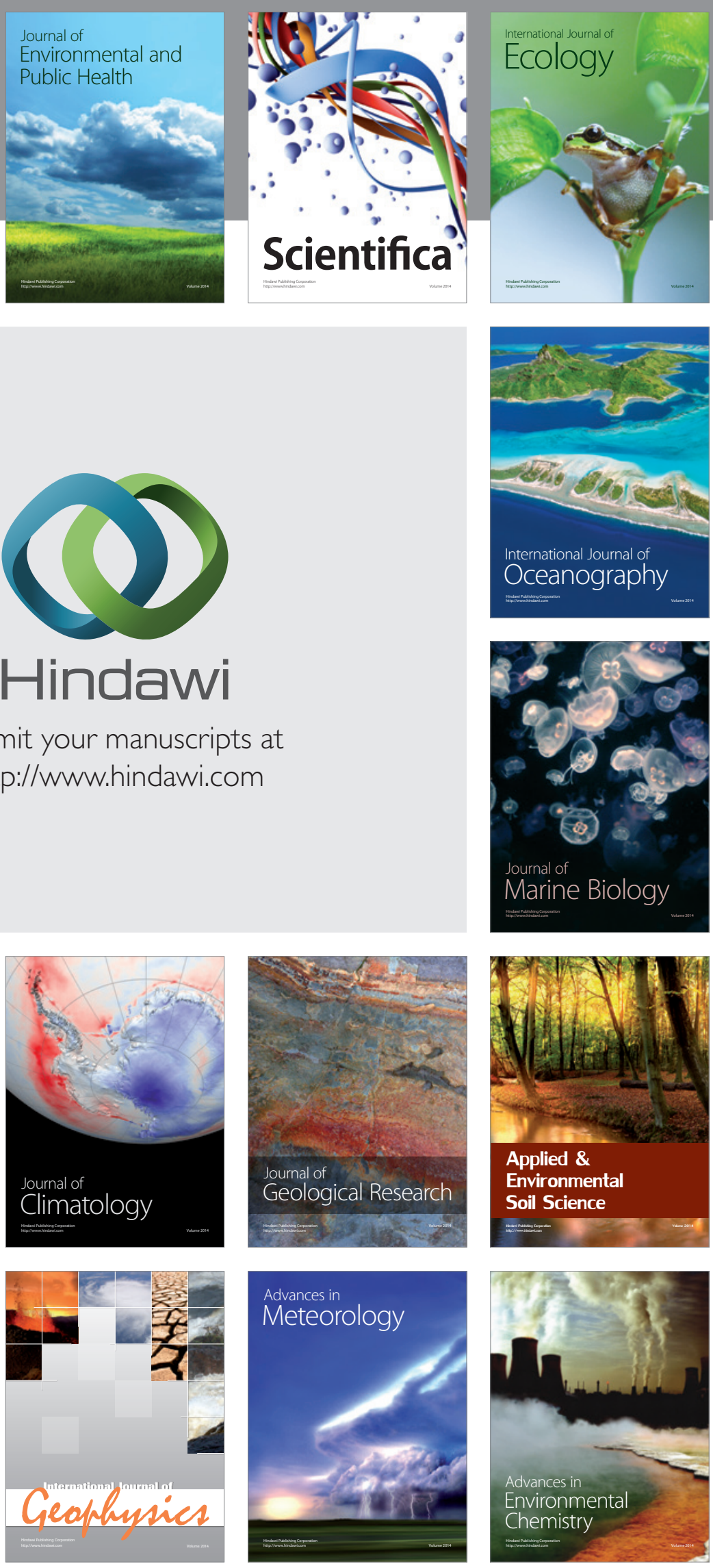